\title{
Üniversite Öğrencilerinin Sosyal Sorun Çözme Becerileri Sürecinde Ö̆̆renci Topluluklarının Rolü: Süleyman Demirel Üniversitesi Örneği
}

\author{
The Role Of Student Communities In The Process Of Social Problem Solving Skills: \\ The Case Of Suleyman Demirel University
}

\author{
Murşit IŞIK* \\ Asena ERDO $\breve{G} A N * *$
}

\begin{abstract}
$\ddot{O} Z$
Insanların sosyal bir varlık olması gerçeğinden hareketle sosyal sorun çözme kavramı ve modeli 30 yılı aşkın bir süredir literatürde yer almakta ve tartışllmaktadır. Sosyal sorun çözme, kişinin günlük yaşamda karşılaştığı özgül sorun durumları için etkili ve uyum sağlayan baş etme tepkilerini keşfetme veya icat etme çabaları olarak tanımlanmaktadır. Bu noktada, yüksekögretim ögrencilerinin içinde bulunduğu genç yetişkinlik döneminin önemli bir geçiş dönemi olduğu göz önüne alınarak, ögrenci kulüplerinin, ögrencilere sosyal bir varlık olarak kendilerini gerçekleştirebilmek için büyük bir firsat sunduğu düşünülmektedir. Bu öğrencilerin, yakın gelecekte kendilerinden beklenen rolleri etkili bir şekilde yerine getirebilmeleri için, sosyal problem çözme becerilerini arttırmaları yaşamlarına olumlu yönde katkı sağlayacaktır. Bu araştırmada, ögrenci topluluklarının yükseköğretim öğrencilerinin sosyal sorun çözme becerilerine etkisini ortaya çıkarmak amaçlanmıştır. Yapılan analizler sonucunda, üniversite öğrencilerinin sosyal sorun çözme becerileri sürecinde topluluklara üye olan üniversite ögrencilerinin sosyal sorun çözme becerilerinin topluluğa üye olmayan üniversite öğrencilerine göre daha gelişmiş olduğu bulunmuştur.
\end{abstract}

\author{
ANAHTAR KELIMELER \\ Sosyal Sorun, Topluluk Ögrencileri, Sosyal Sorun Çözme Becerileri.
}

\begin{abstract}
Based on the fact that people are social entities, the concept and model of social problem solving have been in the literature and have being discussed for more than 30 years. Social problem solving is defined as an effort to discover or produce effective and adaptive overcoming responses to specific problems that a person faces in daily life. At this point, considering that the young adult period of higher education students, it is thought that student clubs provide a great opportunity for students to realize themselves as a social entity.Increasing their social problem-solving skills will contribute to their lives in a positive way in order to fulfill the expected roles of these students effectively in the future. In this study, it is aimed to reveal the effect of student communities on social problem solving skills of higher education students. As a result of the analyzes, it was found that the social problem solving skills of higher education students being members of the communities are more improved than the students who are not members of the community.
\end{abstract}

\section{KEYWORDS}

Social Problem, Student Communities, Social Problem Solving Skills.

\begin{tabular}{|c|c|c|}
\hline \multicolumn{2}{|r|}{$\begin{array}{c}\text { Makale Gelis Tarihi / Submission Date } \\
\text { 20.01.2020 }\end{array}$} & $\begin{array}{c}\text { Makale Kabul Tarihi / Date of Acceptance } \\
18.02 .2020\end{array}$ \\
\hline Attf & $\begin{array}{l}\text { Işı1k, M. ve Erdoğan, A. (2020). Ün } \\
\text { Topluluklarının Rolü: Süleyman De } \\
\text { Yüksekokulu Dergisi, } 23 \text { (1), 240-256. }\end{array}$ & $\begin{array}{l}\text { Sosyal Sorun Çözme Becerileri Sürecinde Öğrenci } \\
\text { neği. Selçuk Universitesi Sosyal Bilimler Meslek }\end{array}$ \\
\hline
\end{tabular}

\footnotetext{
* Dr.Öğr.Üyesi, Süleyman Demirel Üniversitesi, İ̈BF, Çalışma Ekonomisi ve Endüstri İlişkileri Bölümü, mursitisik@ @sdu.edu.tr, ORCID: 0000-00019855-6290

** Süleyman Demirel Üniversitesi, Sosyal Bilimler Enstitüsü, Çalışma Ekonomisi ve Endüstri İlişkileri Ana Bilim Dalı, asenaerdogan95@ gmail.com, ORCID: 0000-0002-9030-191X
} 


\section{GİRIŞ}

Nüfusun hızlı artışı ve değişen hayat standartları, insanların birbirleriyle sürekli etkileşim halinde olmasını ve bunun sonucunda bireyler arası birtakım sorunları da beraberinde getirmektedir. Sorunlar, kişisel ve toplumsal yaşamı şekillendirmeye yönelik tüm faaliyetlerin destekleyici gücüdür ve mühim olan, sorunlardan kaçmak ya da sorunların oluşmasını engellemek değil, sorunların üstesinden gelebilmek ve bir çözüme ulaştırmaktır. Bu da ilk olarak belirli bazı amaçlara varmak amacıyla karşımıza çıkan engelleri ortadan kaldırmaya yönelik çabalarla gerçekleşmektedir.

İnsanlar sosyal bir varlık olarak dünyaya gelmekte ve geliştiği çevrede iletişim içinde olarak sosyal ve kültürel yönden kendilerini geliştirmektedirler. Bu gelişim süreci içerisinde gerçekleştirilen etkinlikler sayesinde bireyler; iletişim yeteneğini arttırma, kendini ifade etme yeteneğini geliştirme ve sosyal sorunlara çözümler getirebilme gibi sosyal bir varlıkta olması gereken özelliklerini giderek geliştirmektedirler. Kişilerin, toplumsal bütünlüğü korumak ve devamlılığını sağlamak için karşılarına çıkan her türlü sosyal sorun ile baş edebilecek becerilere sahip olmaları önemli bir gerekliliktir.

Üniversiteler, kişinin sosyal becerilerinin kazandırılmasında esas ve önemli bir rol oynamaktadır. Bu kurumların mesleki alana yönelik öğretim yapan kurumlar olmasının yanında öğrencilerin sosyal yönelimlerini arttırma ve öğrencilerine kişisel olarak çeşitli konularda pratiğe dayalı beceriler kazandırma misyonu taşıyan kurumlar olması öngörülmektedir. Bu noktada yükseköğretimde öğrenci kulüplerinin öğrencilere sosyal bir varlık olarak kendini gerçekleştirebilmesi için büyük bir firsat sunduğu düşünülmektedir. Özellikle bu öğrencilerin içinde bulunduğu genç yetişkinlik döneminin önemli bir geçiş dönemi olduğu göz önüne alındığında, gelecekte kendilerinden beklenen rolleri etkili bir şekilde yerine getirebilmeleri amacıyla, sosyal problem çözme becerilerini arttırmalarının yaşamlarına olumlu yönde katkıda bulunacağı düşünülerek bu grup üzerinde araştırma yapılmasının yararlı olacağı düşünülmüştür. Bu amaçla araştırmada, D'Zurilla ve Nezu tarafindan 1990 y1lında geliştirilmiş olan "Sosyal Sorun Çözme Envanteri" ne (Social Problem Solving Inventory -SPSI-) göre üniversite topluluk öğrencilerinin sosyal sorun çözme düzeyleri incelenmiştir.

\section{SORUN ÇÖZME KAVRAMI}

Sorun kavramı anlam olarak; çözümlenmesi, öğrenilmesi ve bir sonuca ulaşılması gereken aşamalı ve sıkıntılı bir süreci ifade etmektedir. Bu süreç; konu dağılımlarına, düzeylerine ya da ait oldukları psikolojik boyuta göre farklı şekillerde sınıflandırılabilmektedir (Kalayc1, 2001: 43). Sorun çözme, insan yaşamında karşılaşılan sorunların üstesinden gelmek amacıyla sıklıkla başvurulan bir beceridir (Akça Koca, 2013: 16; Öztürk Can vd., 2009: 39).

Özgül bir sorun için etkili çözüm yöntemlerini belirleyebilmek ise kişi, çift ya da grup tarafından uygulanan bilişsel-davranışsal bir işlem ile gerçekleşmektedir. Bu bilişsel davranışsal işlem; sınırlı bir sorundan doğan olası güçlü çözümlere erişebilmeyi mümkün kılmakta ve çeşitli seçenekler arasından en güçlü çözümü seçme ihtimalini yükseltmektedir (Merzano vd., 1989: 124; D’Zurilla vd., 2004: 13).

Oğuzkan (1974:24), sorun çözmeyi kişinin yeni olay ya da pozisyonlar karşısında var olan bağları açığa çıkarma, yeni bağlar kurma ve istenilen hedefe göre açık bir sonuç edinme eylemi şeklinde ifade etmektedir.

Sorun çözme kavramının en önemli bileşeni olan "sorun" terimi; incelenip öğrenilmesi, düşünülüp çözümlenmesi, bir sonuca ilişkilendirilmesi gereken durum, mesele, problem" olarak tanımlanmaktadır (TDK, 2008). Literatürde bu kavram; çözümü, yaratıcı düşünmeyi gerektiren ciddi bir zor durumu ve bir soru ya da bir dizi soru yoluyla bireyi soruların nedenleri ile sonuçlarını araştırmaya doğru çeviren konum olarak ele alınmaktadır (Oğuzkan, 1974:24).

Sorun çözme süreci; şu anki sorunlu durumdan, istenilen duruma erişmek için gösterilen gayret olarak bilinmektedir (Davidson vd., 1994: 211). Tüm sorunlu durumlarda görülen üç ana özellik; veriler, amaç ve engellerdir. Veriler; sorunlu durum hakkında elde var olan bilgiler, amaç; sorunun istenilen çözüm veya duruma ulaşması, engeller; var olan durumla ulaşılmak istenen durum arasındaki aşılması gereken zorluklar olarak ifade edilmektedir. (Y1ldı, 2006:232). D'Zurilla vd. (2004: 12)'a göre sorun veya sorunsal durum, uyum sağlayıcı bir işlevsellik için bir tepki gerektiren bir durum olarak ifade edilmektedir.

Sorun çözme, belli bir hedefe ulaşabilmek için karşılaşılan tüm güçlükleri ortadan kaldırmaya yönelik bir dizi çabayı içermektedir. Ayrıca psikolojik uyum da önemli bir faktör olup genel yetkinlik ve uyumu artıran bir baş etme stratejisi olarak ele alınmaktadır (D'Zurilla, 1986: 15; D'Zurilla ve Nezu 1990: 159; MaydeuOlivares ve D'Zurilla, 1996: 118). Genel anlamda sorun çözme, öğretilebilir bir yetenektir ve bireyin hem iç hem de dış dünyayla denge içinde yaşamasının göstergesi olan bir beceri olarak düşünülebilir (Erdoğan, 2000: 303). Bu kavram bilişsel, duyuşsal ve davranışsal öğeleri içermesinin yanı sıra, uyum yeteneğini de 
gerektirmektedir. Bu nedenle birçok araştırmacı tarafından sorun çözme süreci, başa çıkma becerisinin alt bileşeni olarak düşünülerek, ruh sağlığının göstergesi olarak belirtilmiştir (Yıldız, 2006:233).

\subsection{Sorun Çözmenin Bileşenleri}

Jahoda (1953, 1958), sorun çözme becerisinin, pozitif ruh sağlığının önemli bir bileşeni olduğunu vurgulamış ve bu beceride meydana gelen rastgele bir yetersizliği "uyumsuzluk ve psikopatoloji” ile birbiriyle bağlantılı olduğunu düşünmüştür. Sorunlarla baședebilme becerisi bilişsel, duyuşsal ve davranışsal tepkileri içermektedir (Reis ve Heppner, 1993: 103). Bununla beraber, iletişim ve sorun çözme becerileri aile fonksiyonlarındaki sağlıklı ilerleyiş olarak tanımlanmaktadır. Sorun çözmenin diğer bileşeni "çözüm" kavramıdır. Bu kavram, sorunlu bir durum karşısında etkili olabilecek bir başaçıkma tepkisi veya başaçıkma tepkileri paterni olarak açıklanmaktadır. Etkili bir çözüm, sadece amaca ulaştıran çözüm olarak tanımlanmamalıdır, aynı zamanda negatif sonuçları en aza indirgeyen, pozitif sonuçları arttıran çözüm olarak tanımlanmalıdır. Çözüm sürecinde elde edilen uygun sonuçlar, kişisel ve sosyal çıktılar, uzun vadeli olduğu kadar kısa süreli olabilir. Tüm taraflarca kabul edilebilir veya tarafların çıkarlarına uygun çıktılar, kişilerarası soruna ilişkin etkili bir çözüme örnek olarak verilebilir (Aktaran: Çekici ve Güçray, 2012: 120).

\subsection{Sosyal Sorun Çözme}

İnsanların sosyal bir varlık olması gerçeğinden yola çıkarak sosyal problem çözme kavramı ve modeli 30 yılı aşkın bir süredir literatürde yer almakta ve tartış1lmaktadır (Haugh, 2006: 396). Sosyal sorun çözme, kişinin günlük yaşamda karşı karşıya geldiği özgül sorun durumları için etkili ve uyum sağlayan başetme tepkilerini keşfetme veya icat etme çabaları olarak tanımlanmaktadır. Bu kavram; sağlık, davranışsal ve duygusal sorunlar gibi "kişi-içi sorunlar, evlilikteki olumsuzluklar, iş ortamındaki çatışmalar gibi "kişilerarası sorunlar", arabanın bozulması, cüzdanın çalınması, anahtarı kaybetme gibi somut olan "kişisel olmayan sorunlar" ve siyasetteki sorunlar, trafik sıkışıklığı, işlenen suç oranlarının artması gibi "toplumsal sorunlar" şeklinde dört ana başlık altında toplanan ve bireylerin işlevselliğini etkileyen her çeşit sosyal içerikli sorunları içermektedir. (D' Zurilla vd., 2004: 18).

D' Zurilla vd. (2004: 21) sosyal problem çözme kavramını, “insanların günlük yaşamda karşı karşıya geldikleri sorunlarla mücadele yollarını bulmak için kendilerinin meydana getirdikleri bilişsel-davranışsal bir süreç" olarak adlandırmışlardır. Bu tanıma göre bir sorunun çözüm sürecinin kişinin kendisi tarafindan şekillendirildiği görülmektedir. Ancak bu süreçte bireyi, kendisinden oluşan ve kendisi dışındaki engellerden kaynaklanan birtakım engeller etkileyebilmekte ve dolayısıyla bireyin etkili davranışı sınırlandırılmaktadır. Bu süreçte D' Zurilla ve Nezu (2007:), sorun çözme sürecini, sorunun alışılmadık olmasının, karmaşa içermesinin, çatışan amaçların varlığının, beceri eksikliklerinin, kaynakların yetersizliğinin, belirsizlik durumunun ve duygusal güçlüklerin etkilediğini ifade etmektedir. Bingham (2004), problem çözme sürecinin yaratıcı düşünme, zeka, duygular, irade ve eyleme geçme, ihtiyaç, amaç, değer, beceri, alışkanlıklar ve tutumlar gibi etmenlerden etkilendiğini benzer bir şekilde öne sürmektedir (Aktaran: Çekici ve Güçray, 2012: 26).

\subsection{Sosyal Sorun Çözme Becerisinin Boyutları}

Sosyal sorun çözme bakış açısı, gerçek yaşamda karşılaşılan sorunların çözümünde güdüsel, tutumsal ve duyuşsal boyutları ele almaktadır. Sosyal sorun çözme terimi, günlük yaşamda karşılaşılan sorunları, içsel ve kişilerarası sorunları çözmeyi vurgulamaktadır (D'Zurilla ve Maydeu-Olivares 1995: 421; Rath vd., 2003: 139). D'Zurilla ve Nezu (2001:214) sosyal sorun çözmeyi ardışık ve birbiri ile etkileşimli beş basamaktan oluşan bir işlem olarak kavramsallaştırmaktadır. Bu basamaklar; sorun yönelimi, sorun tanımı ve formülasyonu, seçenekler oluşturma karar verme çözümü uygulama ve izleme olarak belirtilmiştir. Sosyal sorun çözme modeline göre, sosyal sorun çözme; sorun yönelimi ve sorun çözme becerileri olmak üzere birbirinden bağımsız iki ana unsurdan oluşan, karmaşık, bilişsel, duyuşsal ve davranışsal işlem olarak ifade edilmektedir (Maydeu-Olivares ve D'Zurilla, 1996: 121).

\subsection{Sorun Yönelimi Boyutu}

Sorun yönelimi günlük hayatta karşı karşıya kalınan sorunlar hakkında bir kişinin genel anlamda nasıl düşündüğünü ve neler hissettiğini vurgulayan göreceli olarak dengeli bilişsel-duyuşsal şema ile ilgili motivasyonel bir işlemdir. Aynı zamanda kişinin sorun çözme becerisi ile ilgilidir ve bu sürecin motivasyonel unsurudur (RodrõÂguez-Fornells ve Maydeu-Olivares 2000: 641). Kişilerin genel farkındalık durumunu, algılamasını ve bireyin sorun çözme becerisini yansıtan, yapısal olduğu kadar işlevsel olmayan dengeli bilişsel- 
duyuşsal şemalardır. Bu şemalar sayesinde bireyin belli durumlarda sorun çözme performansı kolaylaşabilmekte veya engellenmektedir (Maydeu-Olivares vd., 2000: 703).

D’Zurilla vd. (2004)'e göre sorun yönelimi, bireyin günlük yaşamda karşılaştığı sorunlar ve kendi sorun çözme becerisi hakkındaki genel inançlarını, değerlendirmelerini ve duygularını yansıtan, dengeli bilişselduyuşsal şema ile bağlantılı metabilişsel bir işlem olarak tanımlanmaktadır ve ayrıca olumlu ve olumsuz olmak üzere ikiye ayrılmaktadır. Sorun yöneliminin unsurları; kişisel güven, olumlu ruh hali ve rutin ve stresli durumlarda duyuşsal düzenleme duygusudur (Elliott vd., 1994: 492; Elliott vd., 1995: 109). Bunun yanı sıra sorun çözmeye yönelik olarak olumsuz yönelime sahip bireyler, hoş olmayan ruh halini düzenlemede güçlüklere sahiptirler ve bu durum depresyon ve anksiyete düzeyini artırmaktadır (Elliott vd., 1996:648). Sorun yönelimi bileşeninin kapsamadığı kısımlar ise, bireyin belirli sorun çözme durumlarında, sorun çözme etkililiğini artıran özgül sorun çözme becerileri ve yetenekleri şeklinde ifade edilmektedir (Maydeu-Olivares ve D’Zurilla, 1996: 122).

\subsection{Sorun Çözme Becerileri Boyutu}

Sorun çözme becerileri, belirli bir sorunlu durum geliştirilen özgün sorun çözme becerisi ve tekniği ile bir çözüm bulmak için gerçekçi araştırma yapma anlamına gelmektedir (Maydeu-Olivares vd., 2000: 703; RodrõÂguez-Fornells ve Maydeu-Olivares, 2000: 641). Sorun çözme becerileri literatürde ilk zamanlar sorun çözme dizgesi (D'Zurilla ve Nezu, 1999:40) şeklinde tanıtılmış, sonrasında sorun çözme tarzı (D'Zurilla vd., 2002: 46) olarak nitelendirilmiştir. Akılcı sorun çözme; etkili sorun çözme becerilerinin akla uygun, sonuçlarının tartılarak ve sistematik olarak uygulanması olarak tanımlanabilen yapıcı bir sorun çözme tarzıdır. Bu tarzın sosyal sorun çözmede önemli bir güdüleyici işlevi olduğuna inanılmaktadır.

Sorun çözme becerileri, kişinin sorunu kavrama, etkili çözümler veya üstesinden gelme yolları bulma amacıyla uyguladığı bilişsel ve davranışsal etkinlikleri anlatmaktadır. Modelin sorun çözme bileşeni sorun çözme yetkinliğine katkı veren, hedef odaklı dört boyuttan oluşmaktadır. Bu boyutlar: 1) sorun tanımlaması ve formülasyonu, 2) seçenek çözümlerin oluşturulmas1, 3) karar verme 4) çözümün gerçekleştirilmesi ve doğrulanması şeklinde rapor edilmiştir (Maydeu-Olivares ve D’Zurilla, 1996: 123).

Sorun tanımlaması ve formülasyonu; sorunla ilgili birçok özgül ve somut veriyi mümkün olduğu ölçüde bir araya getirmek, gereklilikleri ve engelleri belirlemek ve gerçekçi sorun çözme amaçlarını oluşturmak suretiyle sorunu anlaşılması kolay hale getirmeye çalışır. Seçenek çözümlerin oluşturulması; insan, sorun çözme hedefleri üzerinde odaklaşır ve imkanı olduğu sürece olası klasik ya da sıra dışı çözümleri saptamaya çalışır. Karar verme; sorun çözücü farklı çözümlerin sonuçlarını tahmin eder, bunları değerlendirir, karşılaştırma yapar ve en iyi veya olası en etkili çözümü seçer. Son aşama olan çözümü gerçekleştirme ve doğrulama; kişi gerçek hayattaki sorunsal süreçle ilgili olarak seçilen çözümün sonucunu dikkatli bir şekilde izleyerek ve değerlendirmektedir (D’Zurilla vd., 2004: 18).

\subsection{Sosyal Sorun Çözme Envanteri}

'Sosyal Sorun Çözme Envanteri' insanların sosyal sorun çözme becerisini etkili ve kuram temelli değerlendirmeye olanak sağlamaktadır. Literatürdeki çalışmalar incelendiğinde, sosyal sorun çözme konusundaki araştırmaların çoğu bu envanteri kullanmıştır (D'Zurilla 1986: 63; D’Zurilla ve Goldfried, 1971: 120; D'Zurilla ve Nezu, 1990: 159). Bu envanter, araştırmamızın konusunu oluşturan üniversitelerdeki öğrenci topluluklarının karşılaştıkları sorunları, sosyal sorun çözme modeline uygun olarak, nasıl çözdüklerini güvenilir ve geçerli bir biçimde ortaya koyacak bir ölçme aracı olarak açıklamaktadırlar.

Nezu vd. (2004)'ye göre sosyal problem çözme süreci, gerçekte bir genel başa çıkma sürecidir. Etkili problem çözme becerisinin kullanılmasıyla durumsal başa çıkma ve davranışsal yeterliklerde artış meydana gelmektedir. D' Zurilla ve Golfried (1971: 113) sosyal problem-çözme eğitimiyle kişilerin, daha olumlu, daha detaylı düşünme ve çelişkili olmayan davranış farklılıkları gösterdiklerini, bu beceri eğitimi sayesinde kişilerin seçeneklerinin olumlu olarak etkilendiğini rapor eder açıklamaktadırlar. (Aktaran: Çekici ve Güçray, 2012: 26)

\section{2. ÜNIVERSITE ÖĞRENCILLEİNIN SOSYAL SORUN ÇÖZME BECERILLERİ}

Üniversite öğrencileri üzerinde yapılan araştırmaların çoğu, bu öğrencilerin üniversite y1llarında, hayatlarının daha önceki dönemlerinde yaşamadıkları zorluklarla karşılaştıklarını ve bunların üstesinden gelebilmek için oldukça çaba sarf ettiklerini göstermektedir (Duyan ve Gelbal 2008: 10).

Araştırmanın konusu olan üniversite öğrencileri içinde bulundukları gelişimsel döneme bağlı olarak başa çıkmak zorunda oldukları farklı sorunlarla karşılaşmaktadırlar. Üniversite öğrencilerin yaşadığı sorunlar üzerinde yapılan araştırmalar incelendiğinde, esas olarak akademik, sosyal yardım, kişisel ve sosyal ilişkiler 
ile mesleki kariyer planı yapabilme gibi boyutlarda sorunlar yaşadıkları görülmektedir (Türküm vd., 2005: 243; Tunçbilek vd., 1993: 37:Akt. Türküm, 2007: 38).

Üniversite öğrencilerinin karşılaştıkları sorunlarla baş etmede kullandıkları başa çıkma yöntemleri ve sorun çözme kaynaklarına ilişkin yapılan araştırmalar incelendiğinde gençlerin problemlerle başa çıkmada problem odaklı başa çıkma, uzman yardımına başvurma ve sosyal destek alma gibi sağlıklı yolları seçebildikleri gibi aşırı sigara, içki içme, uyuşturucu ve ilaç kullanma, düzensiz yeme gibi ruh ve beden sağliklarını bozucu sağl1ksız yollara başvurdukları saptanmıştır (Türküm vd., 2005: 245).

Üniversite öğrencileri için üniversite yılları hayatlarının daha önceki dönemlerinde yaşamadıkları zorluklarla karşı karşıya geldikleri bir zorlantı dönemi olarak bilinmektedir. Yapılan çeşitli araştırmalar saldırganlık (McMurran vd., 2002:242), kayg1 (Davey, 1994:329) depresyon (Chang ve D’ Zurilla, 1996: 192), öfke ve düşük özgüven ile sosyal problem çözme becerilerindeki yetersizlik arasında yüksek derecede bir ilişki bulunduğunu göstermektedir (Çekici ve Güçray, 2012: 120).

Üniversiteler, kişinin sosyal becerilerinin kazandırılmasında esas ve önemli bir rol oynamaktadır. Bu kurumların mesleki alana yönelik öğretim yapan kurumlar olmasının yanında öğrencilerin sosyal yönelimlerini arttırma ve öğrencilerine kişisel olarak çeşitli konularda pratiğe dayalı beceriler kazandırma misyonu taşıyan kurumlar olması öngörülmektedir. Tam bu noktada, üniversitelerde kurulan farklı alanlara ait öğrenci kulüpleri öğrencilerin ilgi ve istekleri doğrultusunda belli amaçlarla yapılan etkinliklerin gerçekleştirildiği, önemli bir işlev üstlenen bir çatıdır (Eskici ve Aktaş, 2014: 34). Yükseköğretim kanununda belirtildiği üzere kişinin ilgi alanları ve yetenekleri doğrultusunda sosyal ortamlarda yer almaları ve sorumluluk üstlenen insanlar olmaları öngörülmektedir (Yüksek Öğretim Kanunu, 1981). Bu amaçla üniversitelerde etkin olan öğrenci kulüplerinin yükseköğretimin hedefleri ile doğru orantılı olduğunu söylemek mümkündür. Öğrenci kulüpleri, öğrencilerin bir araya gelerek fikir birliği ve işbölümü yapmaları gerektiği sosyal bir ortamdır. Böylece günlük hayatta oldukça sık kullanılan bir kavram olan grup kavramını meydana getirmektedirler. Grup kavramı bize birden fazlayı ifade etmekte ve sosyal psikolojide ortak amaçları, ortak normları ve kendilerini bir grup olarak hisseden insanların bir araya gelmesinden oluşmaktadır.

Grupların özellikleri dikkate alındığında kişilerin esas amaç ve normlar çerçevesinde örgütlü olarak süreklilik sağlayan çalışmalar yaptığı görülmektedir. Böylece kişilerde bir aidiyet duygusundan söz edilebilmektedir. İnsanların eylemlerini içten gelerek yaptığı göz önüne alındığında grup olarak bir şeyler başarma ve bu grubun bir parçası olma eğiliminde oldukları ortaya çıkmaktadır. Bu noktada yükseköğretimde öğrenci kulüplerinin öğrencilere sosyal bir varlık olarak kendini gerçekleştirebilmesi için büyük bir firsat sunduğu düşünülmektedir. Özellikle bu öğrencilerin içinde bulunduğu genç yetişkinlik döneminin önemli bir geçiş dönemi olduğu göz önüne alındığında, yakın gelecekte kendilerinden beklenen rolleri etkili bir şekilde yerine getirebilmeleri amacıyla, sosyal problem çözme becerilerini arttırmalarının yaşamlarına olumlu yönde katkıda bulunacağı düşünülerek bu grup üzerinde araştırma yapılmasının yararlı olacağı düşünülmüştür. (Eskici ve Aktaş, 2014: 35). Bu amaçla araştırmada, D’Zurilla ve Nezu tarafindan 1990 yılında geliştirilmiş olan sosyal sorun çözme envanteri'ne (Social Problem Solving Inventory -SPSI) göre üniversite topluluk öğrencilerinin sosyal sorun çözme düzeyleri incelenmiştir.

Tablo 1. Süleyman Demirel Üniversitesi Sağlık Kültür Ve Spor Bakanlığı 2019-2020 Güz Dönemi Topluluk Sayıları Ve Topluluklara Üye Olan Öğrenci Sayıları

\begin{tabular}{|c|l|r|}
\hline 1 & Kültür ve Kitap Topluluğu & 292 \\
\hline 2 & Halk Oyunları Topluluğu & 202 \\
\hline 3 & Sinema Topluluğu & 381 \\
\hline 4 & Su Sporları Topluluğu & 370 \\
\hline 5 & Gida Topluluğu & 185 \\
\hline 6 & Dans Topluluğu & 94 \\
\hline 7 & Satranç ve Zeka Oyunları Topluluğu & 219 \\
\hline 8 & Endüstri ve Kalite Topluluğu & 1011 \\
\hline 9 & Münazara Topluluğu & 164 \\
\hline 10 & Dağcllık ve Kayak Topluluğu & 202 \\
\hline 11 & Atatürkçü Düşünce Topluluğu & 308 \\
\hline 12 & Tiyatro Topluluğu & 177 \\
\hline 13 & İşaret Dili Topluluğu & 343 \\
\hline 14 & Havacillk Topluluğu & 54 \\
\hline 15 & Galatasaraylılar Topluluğu & 313 \\
\hline 16 & Edebiyat Topluluğu & 144 \\
\hline
\end{tabular}

Selçuk Üniversitesi Sosyal Bilimler Meslek Yüksekokulu Dergisi, Yıl: 2020 Cilt: 23 Sayı:1 


\begin{tabular}{|c|c|c|}
\hline 17 & Uluslararası Kültürel Etkileşim Topluluğu & 162 \\
\hline 18 & Fizik Topluluğu & 168 \\
\hline 19 & Türk Dünyası ve Akraba Toplulukları Topluluğu & 59 \\
\hline 20 & K1zılay Topluluğu & 480 \\
\hline 21 & Türkçe Topluluğu & 262 \\
\hline 22 & Tarih Topluluğu & 175 \\
\hline 23 & Ombudsmanlık ve Arabuluculuk Topluluğu & 59 \\
\hline 24 & Sosyolojik Düşünce ve Felsefe Topluluğu & 288 \\
\hline 25 & İletişim ve Genç Yöneticiler Topluluğu & 275 \\
\hline 26 & Müzik Topluluğu & 297 \\
\hline 27 & Motosiklet Topluluğu & 77 \\
\hline 28 & Arkeoloji Topluluğu & 171 \\
\hline 29 & Fotoğraf Topluluğu & 581 \\
\hline 30 & Milli Kültür Topluluğu & 71 \\
\hline 31 & İnşaat Topluluğu & 901 \\
\hline 32 & Rock Topluluğu & 409 \\
\hline 33 & Uluslararası Öğrenci Topluluğu & 347 \\
\hline 34 & Coğrafya Topluluğu & 115 \\
\hline 35 & Proje Araştırma Geliştirme ve Uygulama Topluluğu & 1104 \\
\hline 36 & Uluslararası Mühendislik ve Teknoloji Öğrencileri Topluluğu & 408 \\
\hline 37 & Genç Sağlıkçılar Topluluğu & 147 \\
\hline 38 & Okçuluk ve Atıcılık Topluluğu & 389 \\
\hline 39 & Akademik Düşünce Eğitim ve Medeniyet Topluluğu & 87 \\
\hline 40 & Yazılım ve Siber Güvenlik Topluluğu & 256 \\
\hline 41 & Politika Tasarım Topluluğu & 116 \\
\hline 42 & Hukuk ve Adalet Topluluğu & 302 \\
\hline 43 & İlahiyet Bilgi ve Düşünce Topluluğu & 72 \\
\hline 44 & Kariyer ve Girişimcilik Topluluğu & 363 \\
\hline 45 & Fizyoterapi ve Engelsiz Yaşam Topluluğu & 161 \\
\hline 46 & Eğirdir Sağllk Hizmetleri MYO Öğrenci Topluluğu & 138 \\
\hline 47 & Ağ1z ve Diş Sağlığı Topluluğu & 395 \\
\hline 48 & Kritik ve Analitik Değerlendirme Topluluğu & 92 \\
\hline 49 & Sosyal Medya Topluluğu & 297 \\
\hline 50 & Süleyman Seba UNİ BJK Topluluğu & 202 \\
\hline 51 & Kimya Mühendisliği Topluluğu & 74 \\
\hline 52 & Genç Bakış Topluluğu & 197 \\
\hline 53 & Küresel Misyon Topluluğu & 17 \\
\hline 54 & Afrika Kültürünü Tanıtma ve Araştırma Topluluğu (AFROKTAT) & - \\
\hline 55 & Diplomasi Topluluğu & 189 \\
\hline 56 & Sanat ve Mimari Topluluğu & 112 \\
\hline 57 & Robotik ve İnovasyon Topluluğu & 146 \\
\hline 58 & Stratejik Düşünce Topluluğu & 173 \\
\hline 59 & Finansal Yönetim Topluluğu & 108 \\
\hline 60 & Türk Yurdu Topluluğu & 63 \\
\hline 61 & Sağlıklı Yaşam Topluluğu & 92 \\
\hline 62 & Genç Yazarlar Topluluğu & 408 \\
\hline 63 & Üniversiteli Aktif Gençlik Topluluğu & 115 \\
\hline 64 & İdealist Gençlik Topluluğu & 69 \\
\hline 65 & Bilgisayar Topluluğu & 207 \\
\hline 66 & Turizm Topluluğu & 3830 \\
\hline 67 & SDÜ Genç Yeşilay Topluluğu & 480 \\
\hline 68 & Moda Topluluğu & 92 \\
\hline 69 & Üniversiteli Trabzonsporlular Topluluğu & 57 \\
\hline 70 & Sağlık ve İyilik Hareketi Topluluğu & 230 \\
\hline 71 & Genç Tema Topluluğu & 1271 \\
\hline 72 & Yeniler Topluluğu & 103 \\
\hline 73 & Türk Tıp Öğrencileri Topluluğu & 326 \\
\hline 74 & Makine ve Otomasyon Topluluğu & 243 \\
\hline
\end{tabular}




\begin{tabular}{|c|l|r|}
75 & Hayvanları Koruma Topluluğu & 494 \\
\hline 76 & Alternatif Enerjili Araç Topluluğu & 141 \\
\hline 77 & Üniversiteli Fenerbahçeliler Topluluğu & 321 \\
\hline 78 & Matematik Topluluğu & 147 \\
\hline 79 & İnovatim Topluluğu & 61 \\
\hline 80 & Siyaset Yönetim Topluluğu & 174 \\
\hline 81 & Çevre Topluluğu & 150 \\
\hline 82 & EskrimTopluluğu & 114 \\
\hline 83 & Biyolojik Araştırma Topluluğu & 174 \\
\hline 84 & Etkinlik Geliştirme Deneyimi Artırma Topluluğu & 76 \\
\hline 85 & Ateş Böceği Topluluğu & 170 \\
\hline 86 & Sayokan Topluluğu & 121 \\
\hline 87 & Ekonomi Yönetim Topluluğu & 166 \\
\hline \multicolumn{2}{|c|}{}
\end{tabular}

\section{ARAŞTIRMANIN METODOLOJISİ}

\subsection{Araştırmanın Evreni, Örneklemi ve Kullanılan Ölçekler}

$\mathrm{Bu}$ araştırmada, Süleyman Demirel Üniversitesi öğrencilerinin sosyal sorun çözme düzeylerinin incelenmesinde fark yaratabileceği düşünülen bazı değişkenlerin etkileri D' Zurilla ve Nezu(1990) tarafından geliştirilmiş, Duyan ve Gelbal (2008) tarafından Türkçe'ye Uyarlama Çalışması yapılmış olan Sosyal Sorun Çözme Envanteri kullanılarak, Üniversite öğrencilerinin sosyal sorun çözme becerileri sürecinde öğrenci topluluklarının rolünü ölçme amacıyla anket yöntemi kullanılarak incelenmiştir.

Araştırma, Süleyman Demirel Üniversitesi 2019-2020 eğitim öğretim güz döneminde öğrenim görmekte olan seçkisiz olarak belirlenen öğrenciler ile Süleyman Demirel Üniversitesi Sağlık kültür spor daire başkanlığından alınan veriler sonucunda kayıtlı öğrenci sayıs1 8620 farklı kişiden oluşan toplam 87 topluluğa uygulanmış ve ankete katılan 650 öğrenci ile gerçekleştirilmiştir.

Anketlerden elde edilen veriler SPSS 25 paket programı ile analiz edilmiştir. Araştırma kapsamına giren kız öğrenci sayısı 416, erkek öğrenci sayısı ise 234'tür. Bu bağlamda Üniversite topluluk öğrencilerinin cinsiyet, yaş, aylık gider, fakülte, vb. faktörler ile sorun çözme becerileri arasındaki ilişki ortaya konmaya çalışılmıştır.

Verilerin toplanması işleminde iki bölümden oluşan anket formundan faydalanılmıştır. Anketin birinci bölümü demografik bilgileri içermektedir. Kişisel bilgi formunda demografik özelliklerin saptanması için cinsiyet, yaş, aylık harcama miktarı, fakülte, herhangi bir topluluğa üye olup olmama durumu, Herhangi bir topluluğa üye iseniz üye olduğunuz topluluğun ismi gibi öğrenim düzeylerinin belirlenmesine ilişkin sorular yer almaktadır.

İkinci bölümde ise D'Zurilla ve Nezu (1990) tarafından geliştirilmiş olan Social Problem Solving Inventory (SPSI); Duyan ve Gelbal (2008) tarafından Türkçe geçerlilik ve güvenirlik çalışması 'Sosyal Sorun Çözme Envanteri'nin Türkçeye Uyarlama Çalışması' yapılmış olan Sosyal Sorun Çözme Envanteri kullanılmıştır. Sosyal Sorun Çözme Envanteri (SSÇE), Sorun Yönelim Ölçeği (SYÖ) ve Sorun Çözme Becerileri Ölçeği (SÇBÖ) olmak üzere iki bölümden oluşmaktadır. Envanter yedi alt boyutu kapsayan yetmiş soru içermektedir. Sorun yönelim ölçeği; Biliş alt boyutu, Duyuş alt boyutu ve Davranış alt boyutu olmak üzere toplam otuz sorudan oluşmaktadır. Sorun Çözme Becerileri Ölçeği ise; Sorun Tanımlaması ve Formülasyonu alt boyutu, Seçenek Çözümlerin Oluşturulması alt boyutu, Karar Verme ve Çözümü Gerçekleştirme alt boyutu ve Doğrulama alt boyutu olmak üzere dört alt boyuttan ve toplam kırk sorudan oluşmaktadır.

Kullanılan envanterin Türkçe formunun çalışması 2008 yılında Duyan ve Gelbal tarafından formun orijinalindeki gibi üniversite öğrencileri için uygulanmıştır. Ankette yer alan ifadelerin yanıtları 5'li Likert ölçeğine göre düzenlenmiştir. Örneğin, "Yaşamımda bir sorun ortaya çıktığında, genellikle mümkün olduğu kadar onu çözmeye çalışmayı sonraya ertelerim." ifadesinin yanıtı için "1-Kesinlikle Katılmıyorum", "2Kat1lıyorum", "3-Fikrim Yok", "4- Kat1lıyorum", "5- KesinlikleKat1lyyorum” şeklinde beş seçenek yer almaktadır. 


\subsection{Araştırmanın Modeli}

\section{Şekil 1. Araştırma modeli}

Demografik Değişkenler

Bağımlı Değiskenler

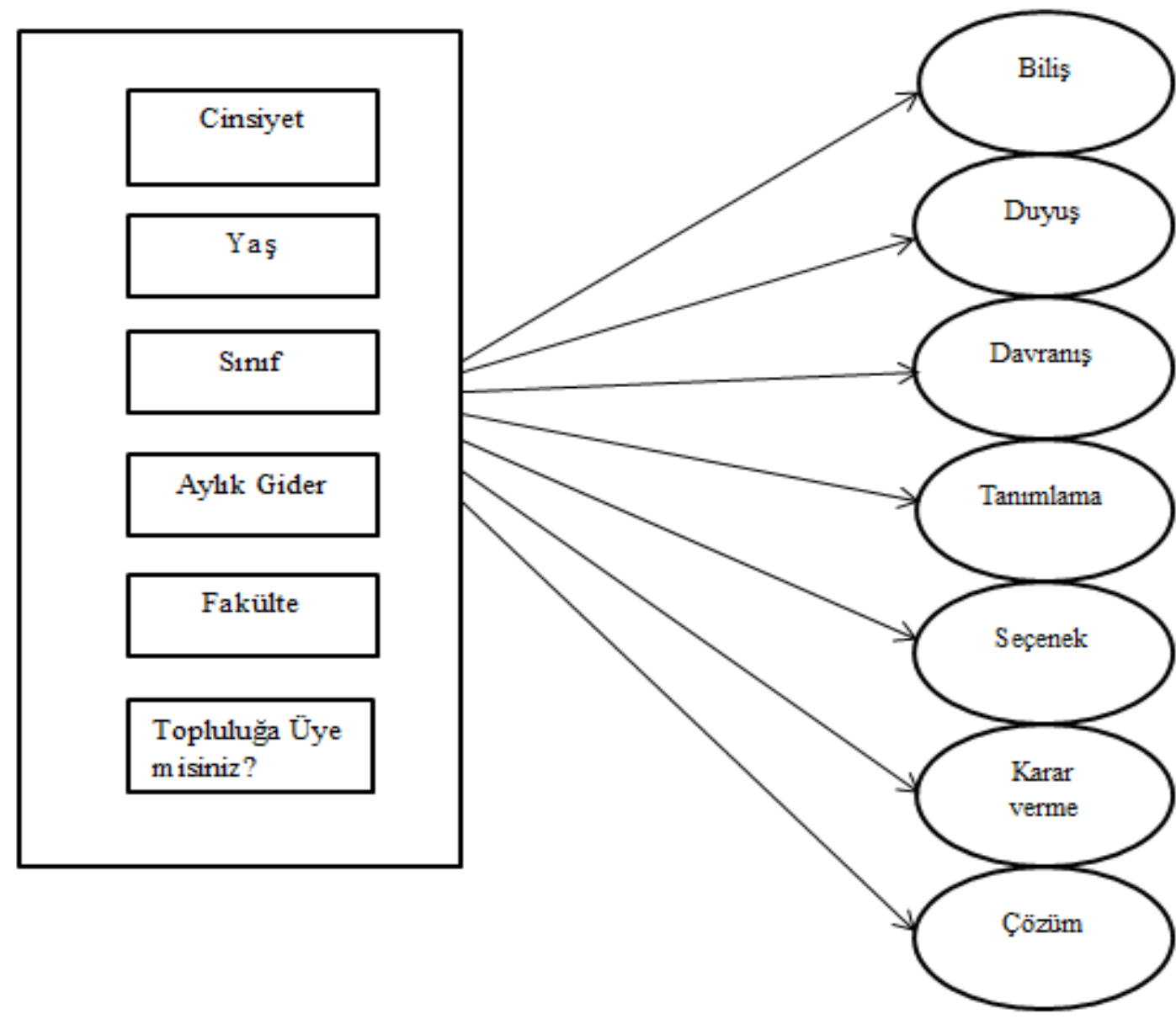

Araştırmada demografik değişkenlerle bağımlı değişkenler arasında fark testleri uygulanmıştır, ölçek içerisinde yer alan sosyal yönelim ölçeğinin alt boyutları ile sosyal sorun çözme becerileri ölçeğinin alt boyutları arasında da korelasyon analizi yapılmıştır.

\subsection{Araştırma Hipotezleri:}

H1: Topluluk üyesi olan öğrenciler ile topluluk üyesi olmayan öğrencilerin sosyal sorun çözme becerileri düzeylerinin alt boyutuna göre arasında anlamlı bir farklılık vardır.

H2: Üniversite ögrencilerinin sorun yönelim düzeyleri ile sorun çözme becerileri arasında pozitif yönlü anlamlı bir ilişki vardır.

H3: Sorun yönelim düzeyinin boyutuna göre, üniversite öğrencilerinin:

H3a: "Cinsiyetlerine" göre sosyal yönelim düzeyinin alt boyutları bakımından farklılaşmaktadır.

H3b: "Yaşlarına" göre sosyal yönelim düzeyinin alt boyutları bakımından farklılaşmaktadır.

H3c: "Sınıflarına" göre sosyal yönelim düzeyinin alt boyutları bakımından farklılaşmaktadır.

H3d: "Aylık Giderlerine" göre sosyal yönelim düzeyinin alt boyutları bakımından farklılaşmaktadır.

H3e: "Fakültelerine" göre sosyal yönelim düzeyinin alt boyutları bakımından farklılaşmaktadır.

H4: Sorun Çözme becerileri boyutuna göre, üniversite öğrencilerinin:

H4a: "Cinsiyetlerine" göre sosyal sorun çözme becerilerinin alt boyutları bakımından farklılaşmaktadır.

H4b: "Yaşlarına" göre sosyal sorun çözme becerilerinin alt boyutları bakımından farklılaşmaktadır.

H4c: "Sinıflarına" göre sosyal sorun çözme becerilerinin alt boyutları bakımından farklılaşmaktadır.

H4d: "Aylık Giderlerine" göre sosyal sorun çözme becerilerinin alt boyutları bakımından farklılaşmaktadır.

H4e: "Fakültelerine" göre sosyal sorun çözme becerilerinin alt boyutları bakımından farklılaşmaktadır. 


\subsection{Analiz ve Bulgular}

\subsubsection{Betimleyici Bulgular}

Üniversite öğrencilerinin sosyal sorun çözme düzeylerinin incelenmesine yönelik olarak Sosyal Sorun Çözme Envanteri kullanılmıştır. Sosyal Sorun Çözme Envanteri' nin Sorun Yönelim (Problem Orientation) ve Sorun Çözme (Problem Solving) ana alt boyutları ile bu boyutlara ait küçük alt boyutlara ilişkin olarak ölçeğin güvenilirliğinin sınanmasında Cronbach's Alfa istatistiğinden yararlanılmıştır. Bu çerçevede her bir boyut için Cronbach's Alfa değerleri ayrı ayrı hesaplanarak Tablo 2' de verilmiştir.

Tablo 2. Cronbach's Alfa Değerleri

\begin{tabular}{|l|c|c|}
\hline ÖLÇEĞíN BOYUTLARI & $\begin{array}{c}\text { SORU } \\
\text { SAYISI }\end{array}$ & $\begin{array}{c}\text { CRONBACH ALPHA } \\
\text { GÜVENILIRLIK } \\
\text { KATSAYISI }\end{array}$ \\
\hline 1. SORUN YÖNELİM ÖLÇEĞİ & 30 & 0,91 \\
\hline a) Biliş Alt Ölçeği & 10 & 0,67 \\
\hline b) Duyuş Alt Ölçeği & 10 & 0,84 \\
\hline c) Davranış Alt Ölçeği & 10 & 0,79 \\
\hline $\begin{array}{l}\text { 2. SORUN ÇÖZME BECERILLERİ } \\
\text { ÖLÇEĞİ }\end{array}$ & 40 & 0,95 \\
\hline $\begin{array}{l}\text { a) Sorun Tanımlaması ve Formülasyonu } \\
\text { 0Alt Ölçeği }\end{array}$ & 10 & 0,91 \\
\hline $\begin{array}{l}\text { b) Seçenek Çözümlerin Oluşturulması Alt } \\
\text { Ölçeği }\end{array}$ & 10 & 0,82 \\
\hline c) Karar Verme Alt Ölçeği & 10 & 0,70 \\
\hline $\begin{array}{l}\text { d) Çözümü Gerçekleştirme ve Doğrulama } \\
\text { Alt Ölçeği }\end{array}$ & 10 & 0,79 \\
\hline $\begin{array}{l}\text { 3. SOSYAL SORUN ÇÖZME } \\
\text { ENVANTERININ TAMAMI }\end{array}$ & 70 & 0,95 \\
\hline
\end{tabular}

Sosyal Sorun Çözme Envanteri' nin güvenirliğini belirlemek için Cronbach's Alpha katsayısı $(0,95)$ hesaplanmıştır. Sosyal Sorun Çözme Envanteri' nin bütününe ve alt boyutlarına ait iç tutarlılık ölçüsü olarak hesaplanan güvenirlik katsayıları istenilen düzeyde olduğu görülmektedir. Yalnızca biliş alt ölçeğinde bir miktar düşüklük görülmekte ve bunun da kabul edilir düzeye çok yakın olması nedeniyle ölçeğin tamamının ve alt boyutlarının güvenirliğinin sağlandığı ifade edilebilir.

Ankete katılan topluluk öğrencilerinin demografik özelliklerine ilişkin frekans dağılımları tablo 3' de yer almaktadır.

Tablo 3. Katılımcıları Demografik Özellikleri

\begin{tabular}{|c|c|c|}
\hline \multicolumn{3}{|l|}{ Cinsiyet } \\
\hline Kadın & 416 & 64 \\
\hline Erkek & 234 & 36 \\
\hline \multicolumn{3}{|l|}{ Yaş } \\
\hline $18-20$ & 183 & 28,2 \\
\hline $21-23$ & 378 & 58,2 \\
\hline 24 ve Üzeri & 89 & 13,7 \\
\hline \multicolumn{3}{|l|}{ Sinif } \\
\hline 1. Sinif & 143 & 22 \\
\hline 2. Sinıf & 79 & 12,2 \\
\hline 3. Sinif & 118 & 18,2 \\
\hline 4. Sinıf ve üzeri & 310 & 47,7 \\
\hline \multicolumn{3}{|l|}{ Aylık Gider } \\
\hline 500 TL'ye kadar & 113 & 17,4 \\
\hline $501-1.000 \mathrm{TL}$ & 270 & 41,5 \\
\hline $1.001-1.500 \mathrm{TL}$ & 178 & 27,4 \\
\hline 1.501 ve üzeri & 89 & 13,7 \\
\hline
\end{tabular}




\begin{tabular}{|lll|}
\hline Fakülte & & \\
\hline İİBF & 293 & 45,1 \\
İletişim & 19 & 2,9 \\
Mühendislik & 88 & 13,5 \\
Sağlık Bilimleri & 54 & 8,3 \\
Teknik Eğitim & 12 & 1,8 \\
Güzel Sanatlar & 7 & 1,1 \\
İlahiyat & 7 & 1,1 \\
Diş Hekimliği & 17 & 2,6 \\
Mimarlık & 4 & 0,6 \\
Fen Edebiyat & 77 & 11,8 \\
Tip & 19 & 2,9 \\
Eğitim & 34 & 5,2 \\
Spor Bilimleri & 9 & 1,4 \\
Hukuk & 10 & 1,5 \\
Total & 650 & 100 \\
\hline Herhangi Bir Topluluğa Üye misiniz? & \\
\hline Evet & 254 & 39,1 \\
Hayır & 396 & 60,9 \\
\hline
\end{tabular}

Yapılan araştırmaya 416 's1 \%64,0 kadın ve 234'ü \%36,0 erkek olmak üzere toplam 650 kişi katılmıştır. Katılımcıların 18-24 yaş aralığında olanların oranı \%28,2, 21-23 yaş aralığında olanların oranı \%58,2, 24 ve üzeri yaş aralığında olanların oranı \%13,7, düzeyindedir. Yaş dağılımı bakımından üniversite topluluk öğrencilerinin ankete katılım düzeyi en yüksek aralık 21-23 yaş arası bireylerdir. Araştırmaya katılan öğrencilerin Sınıf dağılımı incelendiğinde birinci sınıfta okumakta olan öğrencilerin oranı \%22,0, ikinci sınıfta okumakta öğrencilerin oran $1 \% 12,2$, üçüncü sınıfta okumakta olan öğrencilerin oranı $\% 18,2$, dördüncü sinıfta okumakta olan öğrencilerin oranı $\% 47,7$ şeklindedir. Üniversite öğrencilerinin aylık giderleri incelendiğinde 500 TL'ye kadar aras1 gelire sahip olanların oran1 \%17,4, 501-1.000 TL aras1 gelire sahip olanların oran1 41,5, 1.001-1.500 TL üzeri gelire sahip olanların oranı $\% 27,4$ ve 1.501 ve üzeri gelire sahip olanların oranı da 13,7 dir. Ankete katılan üniversite öğrencilerinin fakültelere göre dağılımının oranları incelendiğinde İktisadi ve İdari Bilimler \%45,1, İletişim \%2,9, Mühendislik \%13,5, Sağlık Bilimleri \%8,3, Teknik Eğitim \%1,8, Güzel Sanatlar ve İlahiyat \%1,1 Diş Hekimliği \%2,6, Mimarlık \% 6, Fen Edebiyat \%11,8, Tıp \%2,9, Eğitim \%5,2, Spor Bilimleri \%1,4, Hukuk \%1,5 fakülte oranlarını göstermektedir. Buna göre Fakülte oranlarına bakıldığında en yüksek dağılımın İktisadi ve İdari Bilimler $(\% 45,1)$ olduğu görülmektedir. Son olarak ankete katılan üniversite öğrencilerinin topluluk üyesi olup olmamalarının dağılımı karşılaştırıldığında topluluğa üye olanların oranı $\% 39,1$ iken üye olmayanların oranı $\% 60,9$ dur.

\subsection{2 İstatistiki Bulgular}

Bu kısımda bağımsız değişken olan demografik özellikler ile bağımlı değişken sosyal sorun çözme becerileri ve sosyal yönelim düzey arasında anlamlı fark olup olmadığına ve değişkenler arasında anlamlı bir ilişki olup olmadığına dair analiz ve bulgulara yer verilmiştir.

Tablo 4. Üniversite Öğrencilerinin Sosyal Sorun Çözme BecerilerininAlt Boyutunun, Cinsiyete Göre Fark Testi(T-Testi)

\begin{tabular}{|l|c|c|c|c|c|c|}
\hline & N & Ortalama & Std. Sapma & t & df & p \\
\hline Kadın & 416 & 3,57 & 0,88457 & 2,313 & 648 & $0,021^{*}$ \\
\hline Erkek & 234 & 3,40 & 0,90009 & & & \\
\hline *p $<0,05$
\end{tabular}

Üniversite öğrencilerinin "cinsiyetlerine" göre sosyal sorun çözme becerilerinin alt boyutları bakımından farklılaşmaktadır. Hipotezi sorun tanımlaması ve formülasyonu alt boyutuna göre test edildiğinde sorun çözme becerileri, cinsiyete göre cinsiyete göre anlamlı bir farklılaşma $(\mathrm{p}<.005)$ olduğu görülmüştür. Bu değerlere göre kadınların ortalaması $(3,57)$, "Katılıyorum" erkeklerin ortalaması $(3,40)$ "Kararsızım” düzeyindedir.

Kadınların sosyal sorun çözmede bir sorunun koşullarını ve sınırlamalarını tanımlama ve gerçekçi amaçlar belirleme yetileri erkeklere göre daha gelişmiştir yorumunda bulunulabilir. 
Tablo 5. Üniversite Öğrencilerinin Sosyal Yönelim DüzeylerininAlt Boyutunun, Cinsiyete Göre Fark Testi(T-Testi)

\begin{tabular}{|l|c|c|c|c|c|c|}
\hline & $\mathrm{N}$ & Ortalama & Std.Sapma & $\mathrm{t}$ & $\mathrm{df}$ & $\mathrm{p}$ \\
\hline Kadın & 416 & 2,76 & 0,81374 & 2,657 & 648 & $0,008^{*}$ \\
\hline Erkek & 234 & 2,58 & 0,83089 & & & \\
\hline${ }^{*}<<0,05$
\end{tabular}

Üniversite öğrencilerinin "Cinsiyetlerine" göre sosyal yönelim düzeyinin alt boyutları bakımından farklılaşmaktadır. Hipotezi duyuş alt boyutuna göre test edildiğinde cinsiyete göre anlamlı bir farklılaşma ( $\mathrm{p}<.005)$ olduğu görülmüştür. Buna göre kadınların ortalaması $(2,76)$ "Kararsızım" düzeyinde iken, erkeklerin ortalaması $(2,58)$ "Katılmıyorum" düzeyinde gerçekleşmiştir.Bu değerlere göre kadınların sosyal sorun çözmede erkeklere göre günlük yaşamda karşılaşılan sorunlara uyum sağlayıcı, tutumsal, güdüsel ve duygusal yaklaşım sürdürme yetileri daha gelişmiştir denilebilir.

Tablo 6.Üniversite Öğrencilerinin Topluluk Üyesi Olan Öğrenciler İle Topluluk Üyesi Olmayan Öğrencilerin Sosyal Sorun Çözme Becerileri Düzeylerinin Alt Boyutuna GöreFark Testi(T-Testi)

\begin{tabular}{|c|c|c|c|c|c|c|c|}
\hline $\begin{array}{c}\text { Herhangi bir } \\
\text { topluluğa üye } \\
\text { misiniz? }\end{array}$ & $\mathrm{N}$ & Ortalama & $\begin{array}{c}\text { Std. } \\
\text { Sapma }\end{array}$ & $\mathrm{t}$ & $\mathrm{df}$ & $\mathrm{P}$ \\
\hline & Evet & 254 & 3,62 & 0,83219 & 2,439 & 648 & $0,015^{*}$ \\
\cline { 2 - 8 } & Hayır & 396 & 3,40 & 0,92477 & & & \\
\hline${ }^{*} \mathrm{p}<0,05$
\end{tabular}

Üniversite öğrencilerinin Topluluk üyesi olan öğrenciler ile topluluk üyesi olmayan öğrencilerin sosyal sorun çözme becerileri düzeylerinin alt boyutuna göre arasında anlamlı bir farklılık vardır. Hipotezi sorun tanımlaması ve formülasyonu boyutuna göre test edildiğinde topluluk üyesi olmaya göre anlamlı bir farklılaşma $(\mathrm{p}<.005)$ olduğu görülmüştür. Buna göre topluluğa üye olanların ortalaması $(3,62)$ "Katılıyorum "düzeyinde, topluluk üyesi olmayanların ortalaması $(3,40)$ "Kararsızım" düzeyinde gerçekleşmektedir. Bu değerlere göre üniversite topluluk öğrencilerinin sosyal sorun çözmede topluluk üyesi olmayan öğrencilere göre bir sorunun koşullarını ve sınırlamalarını tanımlama ve gerçekçi amaçlar oluşturma düzeyleri daha gelişmiştir denilebilir.

Tablo 7. Üniversite Öğrencilerinin Sınıf Gruplarına Göre Sosyal Yönelim Düzeyleri Bakımından Karşılaştırılması İçin Varyans Analizi Tablosu

\begin{tabular}{|llllll|}
\hline & $\begin{array}{l}\text { Kareler } \\
\text { Toplamı }\end{array}$ & df & $\begin{array}{l}\text { Ortalama } \\
\text { Kare }\end{array}$ & F & P \\
\hline Gruplar aras1 & 7,589 & 3 & 2,53 & 4,634 & $0,003^{*}$ \\
Gruplar içi & 352,62 & 646 & 0,546 & & \\
\hline
\end{tabular}

$* \mathrm{p}<0,05$

\begin{tabular}{|clll|}
\hline Sinif & $\mathrm{N}$ & Ortalama & Std. Sapma \\
\hline 1. Sinif & 143 & $\mathbf{2 , 5}$ & 0,73766 \\
2. Sinif & 79 & 2,7 & 0,71138 \\
3. Sinif & 118 & 2,64 & 0,74615 \\
4. Sinif & 310 & 2,81 & 0,76971 \\
Total & 650 & 2,61 & 0,745 \\
\hline
\end{tabular}

Araştırma kapsamına alınan üniversite öğrencilerinin "Sınıflarına" göre sosyal yönelim düzeyinin alt boyutları bakımından farklılaşmaktadır. Hipotezi duyuş alt boyutu açısından test edildiği ve üniversite öğrencilerinin sosyal yönelim düzeylerinin, sınıflarına göre $(\mathrm{F}=4,634 ; \mathrm{p}<0.05)$, karşılaştırılması bakımından yapılan varyans analizi sonrasında, birinci sınıf öğrencilerinin ortalaması $(2,5)$ "Katılmıyorum" düzeyine iken, ikinci $(2,7)$, üçüncü $(2,6)$ ve dördüncü $(2,8)$ sınıf öğrencilerinin ortalaması "Kararsızım" düzeyinde gerçekleşmiştir. Sınıf düzeylerine göre gruplar arasında istatistiksel olarak anlamlı derecede farklılık bulunmuştur. Bunun dışında yapılan Post-hoc Tukey testi sonuçlarına göre elde edilen bulgular sonucunda 
birinci sınıf öğrencileri ile ikinci, üçüncü ve dördüncü sınıf öğrencileri arasında anlamlı bir farklılık bulunmuştur. $\mathrm{Bu}$ değerlere göre sınıf düzeyi azaldıkça öğrencilerin günlük yaşamlarında karşılaştıkları sorunlarla uyum sağlayıcı, tutumsal, güdüsel ve duyuşsal yaklaşım sürdürme düzeylerinin de azaldığı söylenebilir. Sınıf düzeyi arttıkça öğrencilerin sorunlarla başa çıkma seviyelerinin arttığı yorumunda bulunulabilir.

Tablo 8. Üniversite Öğrencilerinin Yaş Gruplarına Göre Sosyal Yönelim Düzeyleri Bakımından Karşılaştırılması İçin Varyans Analizi TablosuBetimsel İstatistikler

\begin{tabular}{|llllll|}
\hline & $\begin{array}{l}\text { Kareler } \\
\text { Toplamı }\end{array}$ & df & $\begin{array}{l}\text { Ortalama } \\
\text { Kare }\end{array}$ & F & Sig. \\
\hline Gruplar aras1 & 466,354 & 2 & 233,177 & 3,462 & $0,032 *$ \\
Gruplar içi & 435,743 & 647 & 67,348 & & \\
\hline${ }^{*} \mathrm{p}<0,05$ & & & & & \\
\hline
\end{tabular}

\begin{tabular}{|cccc|}
\hline & $\mathrm{N}$ & Ortalama & Std. Sapma \\
\hline $18-20$ & 183 & 2,50 &, 86095 \\
$21-23$ & 378 & 2,69 &, 80296 \\
24 ve Üzeri & 89 & 2,79 &, 83679 \\
Total & 650 & 2,69 &, 82376 \\
\hline
\end{tabular}

Araştırma kapsamına alınan üniversite öğrencilerinin "Yaşlarına" göre sosyal yönelim düzeyinin alt boyutları bakımından farklılaşmaktadır. Hipotezi duyuş alt boyutu açısından test edildiği ve üniversite öğrencilerinin sosyal yönelim düzeylerinin, yaşları $(\mathrm{F}=3,462 ; \mathrm{p}<0.05)$, bakımından karşılaştırması için yapılan varyans analizi sonrasında 18-20 yaş grubunun ortalaması $(2,5)$ "Katılmıyorum" düzeyine iken, 21-23 $(2,69)$ ve 24 ve üzeri $(2,79)$ yaş gurubundaki öğrencilerin ortalaması "Kararsızım" düzeyinde gerçekleşmiştir. Yaş gruplarına göre gruplar arasında istatistiksel olarak anlamlı derecede farklılık bulunmuştur. Bunun dışında yapılan Post-hoc Tukey testi sonuçlarına göre elde edilen bulgular sonucunda 18-20 ile 21-23 ve 24 ve üzeri yaş grubu arasında anlamlı bir farklılık bulunmuştur. 18-20 yaş grubunun diğer yaş gruplarına göre daha düşük bir ortalamaya sahip olduğu belirlenmiştir. Bu değerlere göre 18-20 Aralığında yaşa sahip bireylerin günlük yaşamlarında karşı karşıya geldikleri sorunlara uyum sağlayıcı, tutumsal, güdüsel ve duyuşsal yaklaşım sürdürme düzeylerinin diğer yaş gruplarına göre daha gelişmemiş olduğu söylenebilir ve bireylerin yaş ortalaması arttıkça sorunlarla başa çıkma düzeylerinin de arttığı yorumunda bulunulabilir.

Tablo 9. Sosyal Yönelim Ve Sorun Çözme Becerileri Ölçeklerinin Alt Boyutları Arasındaki İlişki

\begin{tabular}{|c|c|c|c|c|c|}
\hline \multicolumn{2}{|c|}{ BOYUTLAR } & TANIMLAMA & KARAR & SEÇENEK & ÇÖZÜM \\
\hline \multirow{3}{*}{ BİLIŞ } & $\begin{array}{l}\text { Pearson } \\
\text { Correlation }\end{array}$ &, $643^{* *}$ &, $765^{* *}$ &, $708^{* *}$ &, $736^{* *}$ \\
\hline & Sig. (2-tailed) & 000 & , 000 & , 000 & ,000 \\
\hline & $\mathrm{N}$ & 650 & 650 & 650 & 650 \\
\hline \multirow{3}{*}{ DUYUŞ } & $\begin{array}{l}\text { Pearson } \\
\text { Correlation }\end{array}$ &, $234^{* *}$ &, $568^{* *}$ &, $332^{* *}$ &, $387^{* *}$ \\
\hline & Sig. (2-tailed) & ,000 & ,000 & , 000 & ,000 \\
\hline & $\mathrm{N}$ & 650 & 650 & 650 & 650 \\
\hline \multirow{3}{*}{ DAVRANIŞ } & $\begin{array}{l}\text { Pearson } \\
\text { Correlation }\end{array}$ & $159^{* *}$ &, $537^{* *}$ &, $323^{* *}$ &, $390^{* *}$ \\
\hline & Sig. (2-tailed) & , 000 & , 000 & , 000 & ,000 \\
\hline & $\mathrm{N}$ & 650 & 650 & 650 & 650 \\
\hline
\end{tabular}

Son olarak, Tablo 9'da Sosyal Yönelim ve Sorun Çözme Becerileri Ölçeklerinin alt boyutları arasında bir ilişki olup olmadığını tespit etmek amacıyla korelasyon testi yapılmışırı. 
Sorun Yönelim Ölçeğinin günlük yaşamda karşı karşıya kalınan sorunlara uyum sağlayıcı, tutumsal, güdüsel ve duyuşsal yaklaşımı devam ettirme düzeylerini tanımlayan alt boyutlarından olan Biliş boyutu ile Sorun Çözme Becerileri Ölçeklerinin bir sorunun şartlarını ve sınırlılıklarını tanımlama ve gerçek anlamda çeşitli amaçlar oluşturma düzeylerini tanımlayan Tanımlama $(r=0,64)$, olası çözümler için beyin firtınası yapma düzeylerini tanımlayan Seçenek $(r=0,70)$ ve çözümleri gerçekleştirme, etkililiğini izleme ve gerekli ise düzeltmeler yapma düzeylerini tanımlayan Çözüm $(\mathrm{r}=0,73)$ alt boyutları arasında kuvvetli düzeyli ve anlamlı bir pozitif ilişki vardır.

Sorun Yönelim Ölçeğinin günlük yaşamda karşı karşıya kalınan sorunlara uyum sağlayıcı, tutumsal, güdüsel ve duyuşsal yaklaşımı devam ettirme düzeylerini tanımlayan alt boyutlarından olan Biliş ve seçeneklerin olası sonuçlarını inceleme ve bir sorunun koşulları ve sınırlamaları bağlamında en faydalı olanı seçmeyi tanımlayan Karar Verme $(\mathrm{r}=0,76)$ boyutu arasında ise çok kuvvetli düzeyde anlamlı pozitif bir ilişki vardir.

Sorun Yönelim Ölçeğinin günlük yaşamda karşılaşılan sorunlara uyum sağlayıc1, tutumsal, güdüsel ve duyuşsal yaklaşım sürdürme düzeylerini tanımlayan alt boyutlarından olan Duyuş boyutu ile Sorun Çözme Becerileri Ölçeklerinin olası çözümler için beyin firtınası yapma düzeylerini tanımlayan Seçenek $(\mathrm{r}=0,33)$, çözümleri gerçekleştirme, etkililiğini izleme ve gerekli ise düzeltmeler yapma düzeylerini tanımlayan Çözüm $(\mathrm{r}=0,38)$ ve seçeneklerin olası sonuçlarını inceleme ve bir sorunun koşulları ve sınırlamaları bağlamında en faydalı olanı seçmeyi tanımlayan Karar $(\mathrm{r}=0,56)$ alt boyutları arasında orta düzeyli ve anlamlı bir pozitif ilişki vardir.

Sorun Yönelim Ölçeğinin günlük yaşamda karşılaşılan sorunlara uyum sağlayıc1, tutumsal, güdüsel ve duyuşsal yaklaşım sürdürme düzeylerini tanımlayan Duyuş ve bir sorunun koşullarını ve sınırlamalarını tanımlama ve gerçek anlamda amaçlar oluşturmayı tanımlayan Tanımlama $(r=0,23)$ boyutu arasında ise zayıf düzeyde anlamlı pozitif bir ilişki vardır.

Sorun Yönelim Ölçeğinin günlük yaşamda karşı karşıya kalınan sorunlara uyum sağlayan, tutumsal, güdüsel ve duyuşsal yaklaşımları devam ettirme düzeylerini tanımlayan alt boyutlarından olan Davranış boyutu ile Sorun Çözme Becerileri Ölçeklerinin olası çözümler için beyin firtınası yapma düzeylerini tanımlayan Seçenek $(\mathrm{r}=0,32)$, çözümleri gerçekleştirme, etkililiğini izleme ve gerekli ise düzeltmeler yapma düzeylerini tanımlayan Çözüm $(\mathrm{r}=0,39)$ ve seçeneklerin olası sonuçlarını inceleme ve bir sorunun koşulları ve sınırlamaları bağlamında en faydalı olanı seçmeyi tanımlayan Karar $(\mathrm{r}=0,53)$ alt boyutları arasında orta düzeyli ve anlamlı bir pozitif iliş̧i vardır.

Sorun Yönelim Ölçeğinin günlük yaşamda karşılaşılan sorunlara uyum sağlayıcı, tutumsal, güdüsel ve duyuşsal yaklaşım sürdürme düzeylerini tanımlayan alt boyutlarından olan Davranış boyutu ile ve bir sorunun koşullarını ve sınırlamalarını tanımlama ve gerçekçi amaçlar oluşturmayı tanımlayan Tanımlama $(\mathrm{r}=0,15)$ boyutu arasında ise zayıf düzeyde anlamlı pozitif bir ilişki vardır.

\section{SONUÇ}

Üniversite öğrencilerinin sosyal sorun çözme becerileri sürecinde öğrenci topluluklarının rolünün incelendiği bu çalışmada elde edilen bulgular tartışılmıştır. Üniversite öğrencilerinin topluluk üyesi olan öğrenciler ile topluluk üyesi olmayan öğrencilerin sosyal sorun çözme becerileri düzeylerinin alt boyutuna göre arasında anlamlı bir farklılık vardır. H1. Hipotezinin test edildiği varyans analizi sonucu doğrultusunda anlamlı bir farklılık $(\mathrm{p}<, 005)$ olduğu H1. Hipotezi kabul edilmiştir. Buna göre topluluğa üye olanların ortalaması, topluluk üyesi olmayanların ortalamasından daha yüksektir. Bu değerlere göre sorun çözmede gündelik sosyal ortamdaki meydana gelen sorunlar doğrultusunda üniversite öğrencileri ile topluluk öğrencilerinin sosyal sorun çözme düzeyleri karşılaştırıldığında topluluk üyesi olan öğrencilerin sosyal ortamlarda daha s1k bulunması, toplulukların yaptıkları etkinliklerde yer alması, sosyal ortamlarını geliştirmesi, topluluk adına karar alma, topluluk ile hareket etme güdülerinin daha etkin olması sonucunda bir sorunla karşılaştıklarında bu sorunun koşullarını ve sınırlamalarını tanımlama ve daha gerçekçi amaçlar oluş̧urma düzeyleri topluluklara katılmayan öğrencilere göre daha gelişmiştir denilebilir.

Üniversite öğrencilerinin sorun yönelim düzeyleri ile sorun çözme becerileri arasında pozitif yönlü anlamlı bir ilişki vardır. H2. Hipotezinin test edildiği korelasyon analizi sonucunda sorun yönelim düzeyleri ile sorun çözme becerileri arasında karşılıklı olarak pozitif yönlü anlamlı bir ilişki bulunmuştur. Bu durumda $\mathbf{H 2}$.

\section{Hipotezi kabul edilmiştir.}

Üniversite ögrencilerinin cinsiyetlerine göre sosyal yönelim düzeyinin alt boyutları bakımından farklılaşmaktadır.H3a. Hipotezinin test edildiği T-testi sonucunda cinsiyete göre anlamlı bir farklılaşma $(\mathrm{p}<, 005)$ olduğu görülmüştür. Bu durumda H3a. Hipotezi kabul edilmiştir. Buna göre kadınların ortalamas1 erkeklerin ortalamasından daha yüksektir. Bu değerlere göre kadınların sosyal sorun çözmede erkeklere göre 
günlük yaşamda karşısına çıkan sorunlara ve sorunları çözme becerisine genelleştirilmiş bilişsel değerlendirme, nedensel yüklemeler, kendine yeterlik beklentileri ve sonuç beklentilerine ilişkin farkındalığını ve ona atfettiği değerlerin karşılaşılan sorunlara uyum sağlayıcı, yaklaşım sürdürme yetileri daha gelişmiştir denilebilir.

Araştırma kapsamına alınan üniversite öğrencilerinin, yaşlarına göre sosyal yönelim düzeyinin alt boyutları bakımından farklılaşmaktadır. H3b. Hipotezinin test edildiği ve üniversite öğrencilerinin, sosyal sorun düzeylerinin, "Yaşlarına" göre karşılaştırılması bakımından yapılan varyans analizi sonrasında yaş gruplarına göre gruplar arasında istatistiksel olarak anlamlı derecede farkl11ık $(\mathrm{F}=3,462 ; \mathrm{p}<0.05)$ bulunmuştur. Bunun dışında yapılan Post-hoc Tukey testi sonuçlarına göre elde edilen bulgular sonucunda 18-20 ile 21-23 ve 24 ve üzeri yaş grubu arasında anlamlı bir farklılık bulunmuştur. Bu durumda H3b Hipotezi kabul edilmiştir. 1820 yaş grubunun diğer yaş gruplarına göre daha düşük bir ortalamaya sahip olduğu belirlenmiştir. Bu değerlere göre 18-20 aralığında yaşa sahip bireylerin günlük yaşamlarında karşı karşıya geldikleri sorunlara uyum sağlayıc1, tutumsal, güdüsel ve duyuşsal yaklaşım sürdürme düzeylerinin diğer yaş gruplarına göre daha gelişmemiş olduğu söylenebilir ve bireylerin yaş ortalaması arttıkça sorunlarla başa çıkma düzeylerinin de arttığ yorumunda bulunulabilir.

Araştırma kapsamına alınan üniversite öğrencilerinin sınıflarına göre sosyal yönelim düzeyinin alt boyutları bakımından farklılaşmaktadır.H3c. Hipotezinin test edildiği ve üniversite öğrencilerinin sosyal yönelim düzeylerinin, "Sınıflarına" göre $(\mathrm{F}=4,634 ; \mathrm{p}<0.05)$, karşılaştırılması bakımından yapılan varyans analizi sonrasında sınıf düzeylerine göre gruplar arasında istatistiksel olarak anlamlı derecede farklılık bulunmuştur. $\mathrm{Bu}$ durumda H3c. Hipotezi kabul edilmiştir.. Bu değerlere göre sınıf düzeyi azaldıkça öğrencilerin günlük yaşamlarında karşılaştıkları sorunlarla uyum sağlayıcı, tutumsal, güdüsel ve duyuşsal yaklaşım sürdürme düzeylerinin de azaldığı söylenebilir. Sınıf düzeyi arttıkça öğrencilerin sorunlarla başa çıkma seviyelerinin arttığ 1 yorumunda bulunulabilir.

Araştırma kapsamına alınan üniversite öğrencilerinin sosyal yönelim düzeyinin alt boyutları bakımından "Fakültelerine" göre farklılaşmaktadır. H3e. Hipotezinin test edildiği ve üniversite öğrencilerinin Sosyal Yönelim düzeylerinin, fakültelerine göre karşılaştırılması bakımından yapılan varyans analizi sonrasında gruplar arasında istatistiksel olarak anlamlı derecede farklılık bulunmamıştır(p>0.05). H3e. Hipotezi reddedilmiştir.

Üniversite öğrencilerinin sorun çözme becerilerinin alt boyutları bakımından "Cinsiyete" göre farklılaşmaktadır.H4a. Hipotezi test edildiğinde sorun çözme becerileri, cinsiyete göre anlamlı bir farklılaşma $(\mathrm{p}<.005)$ olduğu görülmüştür.

Bu değerlere göre kadınların ortalaması $(3,57)$, "Katıllyorum" erkeklerin ortalaması $(3,40)$ "Kararsızım" düzeyindedir. Kadınların sosyal sorun çözmede bir sorunun koşullarını ve sınırlamalarını tanımlama ve gerçekçi amaçlar belirleme yetileri erkeklere göre daha gelişmiştir yorumunda bulunulabilir. H4a. Hipotezi kabul edilmiştir

Araştırma kapsamına alınan üniversite öğrencilerinin Üniversite öğrencilerinin sorun çözme becerilerinin alt boyutları bakımından "Yaşlarına" göre farklılaşmaktadır.H4b. Hipotezinin test edildiği ve üniversite öğrencilerinin Sosyal Sorun Çözme Becerilerinin, yaşlarına göre karşılaştırılması bakımından yapılan varyans analizi sonrasında gruplar arasında istatistiksel olarak anlamlı derecede farklılık bulunmamıştır(p $>0.05)$. H4b. Hipotezi reddedilmiştir.Araştırma kapsamına alınan üniversite öğrencilerinin Üniversite öğrencilerinin sorun çözme becerilerinin alt boyutları bakımından "Sınıflarına" göre farklılaşmaktadır. H4c. Hipotezinin test edildiği ve üniversite öğrencilerinin sosyal sorun çözme becerilerinin, sınıflarına göre karşılaştırılması bakımından yapılan varyans analizi sonrasında gruplar arasında istatistiksel olarak anlamlı derecede farklılık bulunmamıştır(p>0.05). H4c. Hipotezi reddedilmiştir.

Araştırma kapsamına alınan üniversite öğrencilerinin Üniversite öğrencilerinin sorun çözme becerilerinin alt boyutları bakımından "Aylık Giderlerine" göre farklılaşmaktadır. H4d. Hipotezinin test edildiği ve üniversite öğrencilerinin sosyal sorun çözme becerilerinin, aylık giderlerine göre karşılaştırılması bakımından yapılan varyans analizi sonrasında gruplar arasında istatistiksel olarak anlamlı derecede farklilık bulunmamıştır ( $\mathrm{p}>0.05)$. H4d. Hipotezi reddedilmiştir.

Araştırma kapsamına alınan üniversite öğrencilerinin Üniversite öğrencilerinin sorun çözme becerilerinin alt boyutları bakımından "Fakültelerine" göre farklılaşmaktadır. H4e. Hipotezinin test edildiği ve üniversite öğrencilerinin sosyal sorun çözme becerilerinin, fakültelerine göre karşılaştırılması bakımından yapılan varyans analizi sonrasinda gruplar arasında istatistiksel olarak anlamlı derecede farkl11ık bulunmamıştır(p>0.05). H4e. Hipotezi reddedilmiştir. 
Araştırmadan elde edilen bulgu ve sonuçlar doğrultusunda üniversite öğrencilerinin sosyal sorun çözme becerileri sürecinde topluluklara üye olan üniversite öğrencilerinin sosyal sorun çözme becerilerinin topluluğa üye olmayan üniversite öğrencilerine göre daha gelişmiş olduğunu söyleyebiliriz. Üniversite öğrencilerinin sosyal sorun çözme becerilerinin daha fazla gelişmesine yönelik olarak öğrenci topluluklarına üye olmaları ders dışı sosyal, sportif, toplumsal, kültürel faaliyetlerde bulunmalarının yanı sıra sosyal gelişimlerine önemli derecede katkı sağlayan topluluk faaliyetlerine katılmaları kişisel olarak gelişimlerini sağladığı gibi sosyal sorunlarla başa çıkma süreçlerini de hızlandırmaktadır denilebilir. 


\section{KAYNAKÇA}

Akça Koca, D. (2013). “Bir Aile Eğitim Programının Evli Annelerin Evlilik Doyumu, Evlilikte Sorun Çözme Becerisi Ve Psikolojik İyi Oluşuna Etkisi” Yüksek Lisans Tezi, Marmara Üniversitesi Eğitim Bilimleri Enstitüsü, İstanbul.

Chang, E.C., D' Zurilla, T.J. (1996), "Relations between problem orientation and optimism, pessimism and trait affectivity", Behaviour Research and Therapy, 34, 185-194.

Çekici, F., Ve Güçray, S. S. (2012). "Problem Çözme Terapisine Dayalı Beceri Geliştirme Grubunun Üniversite Öğrencilerinin Sosyal Problem Çözme Becerileri Öfkeyle İlişkili Davranış Ve Düşünceler İle Sürekli Kaygı Düzeylerine Etkisi”. Çukurova Üniversitesi Sosyal Bilimler Enstitüsü Dergisi, 21(2), 103-128.

D’zurilla, T. J. (1986). Problem-Solving Therapy: A Social Competence Approach To Clinical İntervention. New York: Springer.

D'zurilla, T. J. Ve Goldfried, M. R. (1971). Problem Solving And Behavior Modification. Journal Of Abnormal Psychology, 78, 107-126.

D’zurilla, T. J. Ve Maydeu-Olivares, A. (1995). Conceptual And Methodological İssues İn Problem-Solving Assessment. Behavior Therapy, 26, 409-432.

D'zurilla, T. J. Ve Nezu, A. M. (1982). Social problem solving in adults. In P. C. Kendall (Ed.). Advances in Cognitivebehavioral Research And Therapy (Vol. 1, pp. 201-244). New York: Academic Press.

D'zurilla, T. J. Ve Nezu, A. M. (1990). Development and preliminary evaluation of the Social Problem-Solving Inventory. Psychological Assessment: A Journal of Consulting and Clinical Psychology, 2, 156-163.

D’zurilla, T. J. Ve Nezu, A. M. (1999). Problem-solving therapy: A Social Competence Approach To Clinical İntervention (2nd ed.). New York: Springer.

D'zurilla, T. J. Ve Nezu, A. M. (2001) Problem-solving therapies. In K. S. Dobson (Ed.), Handbook of CognitiveBehavioral Therapies (2nd ed., pp.211-245). New York: Guilford Press.

D'zurilla, T. J., Nezu, A. M. Ve Maydeu-Olivares, A. (2002). The social problem-solving inventory-revised (SPSI-R): technical manual. North Tonawanda, NY: Multi-Health Systems, Inc.

D’zurilla, T.J. Nezu, A.M. Ve Maydeu-Olivares A. (2004). Social Problem Solving: Theory And Assessment. (Ed. Thomas J D'Zurilla; Edward C Chang; Lawrence J Sanna). Social problem Solving : Theory, Research, And Training, ss. 11-27, Washington, DC : American Psychological Association.

Davey, G.C. L. (1994). "Worrying, Social Problem Solving Abilities And Problem Solving Confidence”, Behaviour Research and Therapy, 32, 327-330.

Davidson, J. E., Deuser, R., Ve Sternberg, R.J. (1994). “The Role of Metacognition in Problem Solving”. (Ed: Metcalfe, J. \& Shimamura, A.P. ), Metacognition: Knowing About Knowing, Cambridge, MA: MIT, Press (pp. 207-226).

Elliott, T., Herrick, S., Macnair, R. Ve Harkins, S. (1994). "Personality correlates of selfappraised Problem-Solving Ability: Problem Orientation And Trait Affectivity" Journal of Personality Assessment, 63, 489-505.

Elliott, T. R., Sherwin, E., Harkins, S. Ve Marmarosh, C. (1995). "Self-Appraised Problem-Solving Ability, Affective States, And Psychological Distress", Journal of Counseling Psychology, 42, 105-115.

Elliott, T., Shewchuk, R., Richeson, C., Pickelman, H. Ve Franklin, K. W. (1996). "Problem-Solving Appraisal And The Prediction Of Depression During Pregnancy And İn The Postpartum Period”, Journal of Counseling and Development, 74, 645-651.

Eskici, M., Ve Aktaş, R. (2014). “Üniversite Öğrencilerinin Öğrenci Kulüplerine Yönelik Görüşleri”. Asya Öğretim Dergisi, 2 (1 (ÖZEL)), 31-40.

Haugh J.A. (2006). "Specifity and social problem-solving: Relation to depressive and anxious Symptomology", Journal of Social and Clinical Psychology, 25, 392-403.

Kalaycı, N. (2001). Sosyal Bilimlerde Problem Çözme, Ankara Gazi Kitapevi.

Kaptan, F. (1999), Fen Bilgisi Öğretim, Üçüncü Baskı. İstanbul: MEB Yayınları.

Karasar, N. (2000). Bilimsel Araştırma Yöntemi, Onuncu Baskı. Ankara: Nobel Kaptan,

Karasar, N. (2004) Bilimsel Araştırma Yöntemi, Nobel Yayın Dağıtım.

Maydeu-Olivares, A., D’ Zurilla, T.J. (1996). “A Factor-Analytic Study Of The Social Problem Solving Inventory: An Integration Of Theory And Data", Cognitive Therapy and Research, 20, 115-133.

Maydeu-Olivares A., Rodrõâguez-Fornells, A., Gomez-Benito J. Ve D’zurilla, T.J. (2000). Psychometric properties of the Spanish adaptation of the Social Problem-Solving Inventory-Revised (SPSI-R), Personality and Individual Differences, 29, 699-708.

Mcmurran, M., Blair, M., Egan, V. (2002). "An investigation of the correlations between aggression, impulsiveness, social problem solving and alcohol use", Aggressive Behavior, 28, 439-445.

Merzano, R ; Brandt, R; Hughes, C. (1989). Dimensions of Thinking. USA: Semline Inc. Nezu, A. M. (1987) “A ProblemSolving Formulation For Depression: A Literature Review And Proposal Of A Pluralistic Model" Clinical Psychology Review, 7, 121-144.

Oğuzkan, F. (1974) Eğitim Terimleri Sözlüğü. Ankara: Türk Dil Kurumu Yayınları.

Rath, Jf, Hennessy, Jj. Ve Diller L. (2003). "Social Problem Solving and Community Integration in Postacute Rehabilitation Outpatients With Traumatic Brain Injury”, Rehabilitation Psychology, 48, 137-144. 
Reis, S. D. Ve Heppner. P. P. (1993). "Examination of coping resources and family adaptation in mothers and daughters of incestuous versus nonclinical families", Journal of Counseling Psychology, 40 (1), 100-108.

Resmi Gazete, (1981). Yükseköğretim Kanunu, No. 2547, 4 Kasım 1981. Resmi Gazete, (17506), 6.

Rodrõâguez-Fornells A. Ve Maydeu-Olivares A. (2000). "Impulsive/careless problem solving style as predictor of subsequent academic achievement", Personality and Individual Differences, 28, 639-645.

Samanc1, O., Ve Uçan, Z. (2015). "Sinif Ögretmeni Adaylarinin Sosyal Sorun Çözme Beceri Düzeylerinin Incelenmesi”, Bartin Üniversitesi Egitim Fakültesi Dergisi, 152-162

Shewchuk, R., Johnson, M. Ve Elliott, T. (2000). Self-Appraised Social Problem-Solving Abilities, Emotional Reactions, And Actual Problem-Solving Performance. Behaviour Research and Therapy, 38, 727-740.

Öztürk Can H., Öner İ. Ö. (2009). Çelebi E. "Üniversite Öğrencilerinde Eğitimin Sorun Çözme Becerisine Etkisinin İncelenmesi”. Firat Sağlık Hizmetleri Dergisi, 4(10): 35-58.

Tunçbilek, E., Koç, İ., Albayrak, F., Özsoy, A. E., Ve Tokcan, S. (1993). "Hacettepe Üniversitesi yurt araştırması. Hacettepe Üniversitesi Merkez ve Beytepe Yurtları'nda Kalan Öğrencilerin Sosyal ve Demografik Özellikleri ve Üniversite’ye İlişkin Sorunları”, Hacettepe Üniversitesi Nüfus Etütleri Enstitüsü, Hacettepe Üniversitesi Basımevi.

TDK, (2008). Güncel Türkçe Sözlük. http://www.tdk.gov.tr/ TR/BelgeGoster. aspx. (10.12.2019).

Türküm, A.S. (2007). Üniversite Gençliğine Yönelik Psikolojik Danışma ve Rehberlik Hizmetleri. Bölüm 11, Gelişen Psikolojik Danışma ve Rehberlik: Meslekleşme Sürecindeki İlerlemeler Cilt I, (Editörler: R. Özyürek, F. KorkutOwen, D. W. Owen), Nobel Yayın Dağıtım, Ankara. Üniversitesi Yayınları, İstanbul.

Türküm, A.S., Kızıltaş, A., Bıyık, N., Yemenici, B. (2005). "Üniversite Öğrencilerinin Aile İşlevleri Algılarının İncelenmesi”. Kuram ve Uygulamada Eğitim Bilimleri Dergisi, 5(1), 229-262.

Yıldız, S. A, (2003). "Ebeveynin Problem Çözme Becerisini Geliştirmeye Yönelik Deneysel Bir Çalışma", Yayınlanmamış Doktora Tezi, İstanbul Üniversitesi, Sosyal Bilimler Enstitüsü, İstanbul.www.sdu.edu.tr (01.12..2019). 